\title{
Effect of altitude variations on summer pea crop in Poonch Division of Azad Jammu and Kashmir
}

\author{
Nadeem Akhtar Abbasi ${ }^{1 *}$, Muhammad Shafique ${ }^{2}$, Sheraz Qamar ${ }^{1}$, \\ Abdul Ahad Qureshi ${ }^{1}$, Ishfaq Ahmad Hafiz ${ }^{1}$ and Irfan Ali $^{1}$ \\ 1. Department of Horticulture, Pir Mehr Ali Shah Arid Agriculture University Rawalpindi-Pakistan \\ 2. University of Agriculture, Faisalabad, Sub-campus Burewala-Vehari-Pakistan \\ *Corresponding author's email: nadeemabbasi65@yahoo.com
}

Citation

Nadeem Akhtar Abbasi, Muhammad Shafique, Sheraz Qamar, Abdul Ahad Qureshi, Ishfaq Ahmad Hafiz and Irfan Ali. Effect of altitude variations on summer pea crop in Poonch Division of Azad Jammu and Kashmir. Pure and Applied Biology. Vol. 9, Issue 3, pp1911-1919. http://dx.doi.org/10.19045/bspab.2020.90204

\begin{tabular}{|c|c|c|c|}
\hline Received: $13 / 02 / 2020$ & Revised: $27 / 04 / 2020$ & Accepted: 06/05/2020 & Online First: $22 / 05 / 2020$ \\
\hline
\end{tabular}

\section{Abstract}

Pea is one of the most liked high value vegetable crop which is mostly grown in plains during winters. For sustainable production it is necessary to grow offseason pea crop at higher altitudes where summer is relatively cold. Field studies were conducted at three different altitudes of Poonch Division of Azad Jammu and Kashmir (Pallandri Gorah, Rawalakot city and Tolipir Bunbeck) to identify the best suitable location for offseason pea cultivation. Therefore, commercial pea cv. 'Meteor' was grown during spring season to analyse the quantitative traits at three different altitudes. Results showed that seed emergence was significantly higher (92.38\%) at Pallandri Gorah location; whereas, plant stem length (43.53 $\mathrm{cm})$, number of branches plant ${ }^{-1}$ (5.58), number of leaves plant ${ }^{-1}$ (87.14), number of flowers plant $^{-1}(40.2)$, pods plant ${ }^{-1}(25.6)$, pod length $(6.59 \mathrm{~cm})$, number of seeds pod ${ }^{-1}(5.13)$, fresh seed weight plant $^{-1}$ (48.76 g), fresh seed yield hectare ${ }^{-1}$ (8.02 tons) were significantly higher in pea plants grown at Tolipir Bunbeck location. Meanwhile, fresh pod yield plant ${ }^{-1}(83.8 \mathrm{~g})$ and fresh pod yield hectare ${ }^{-1}$ (13.78 tons) were also high at Tolipir Bunbeck location. Evidently, Tolipir Bunbeck came out to be the most suitable location among all three altitudes for sustainable production of offseason summer pea crop.

Keywords: Altitude; Azad Kashmir; Location; Pea; Poonch

\section{Introduction}

Pea (Pisum sativum L.) is the second most important food legume worldwide and is widely cultivated in temperate regions for its fresh green seed $[1,2]$. Pea yield per unit area in Pakistan is 178231 tonnes [3] which is less than the international standard due to factors like incidence of diseases, poor cultural practices, and pest attack leading in reduced production [4]. Therefore, it is necessary to increase the yield of peas with better quality in Pakistan [5]. There is persistent demand of peas throughout the year; however, the major share of pea crop comes from plains where it is grown in winter season [6]. On the other hand, very little production of peas from Kaghan valley cannot fulfil the demand of consumers, resulting in higher prices during summer. Therefore, sustainable production of peas by growing them at higher altitudes during summer is necessary to fill the gap between demand and supply [7]. High value vegetables are getting popular among farmers of mid-hill areas as they increase income level of rural 
people [8]. These high value crops grown both in summer and autumn makes the availability of fresh green pods of peas from March onwards till the end of October [9]. Altitude can serve as a proxy for temperature as average temperature decreases with each $100 \mathrm{~m}$ above sea level (asl); thereby, making possible the cultivation of cool season crops of plain to grow and produce in summer at higher altitudes [10]. Climate of hilly areas provide comparative advantage of growing high value vegetables [11]. Peas grow best in 5.8-6.8 $\mathrm{pH}$ soils with $15 \mathrm{~mm}$ to $99 \mathrm{~mm}$ annual rainfall; however, they are sensitive to temperature above $30^{\circ} \mathrm{C}$ [7]. Area of Poonch Division is hilly and rugged in topography hence, suitable for the cultivation of high value cool season plain crops. Pallandri Gorah is situated in the south of Rawalakot city, while Tolipir Bunbeck is located in east of Rawalakot city, where temperature ranges from 10$30^{\circ} \mathrm{C}$ during summer [12].

The highlands of Khyber Pakhtunkhwa are used for the early pea production due to colder climate. There is also the tendency of proxy pea production in the hilly areas of Azad Jammu and Kashmir (AJK). At present there is no literature available on growing high value off season pea crop at different altitudes of AJK. Therefore, a study was planned to identify the best location in hilly areas of Poonch division of AJK for probability of offseason summer production of pea crop. Commercial and approved pea cv. 'Meteor' was cultivated to check growth and yield parameters in order to identify the suitable pockets for summer pea crop with the objective to set a trend of pea cultivation in AJK.

\section{Materials and methods}

Three locations in Pooch division of Azad Jammu and Kashmir i.e. Pallandri (1508 m above sea level $\left.33.71{ }^{\circ} \mathrm{N}-73.68{ }^{\circ} \mathrm{E}\right)$, Rawalakot city (1645 m above sea level $\left.33.85^{\circ} \mathrm{N}-73.75{ }^{\circ} \mathrm{E}\right)$ and Tolipir Bunbeck (2124 $\mathrm{m}$ above sea level $33.88^{\circ} \mathrm{N}-73.92$ $\left.{ }^{\circ} \mathrm{E}\right)$ were selected to study the effect of altitude on growth and seed yield of high value pea cv. 'Meteor' during the spring season 2014. Salient features of pea cv. 'Meteor' are given in (Table 1) and seeds were sown during first week of May. Experiment was laid out under Randomized Complete Block Design. There were five subplots of the area $4.5 \mathrm{~m}^{2}$ in each treatment which were considered as replications. Row $\times$ row distance of $1 \mathrm{~m}$ and plant $\times$ plant distance of $8 \mathrm{~cm}$ was maintained. Total 370 seeds were sown in each treatment while total numbers of seeds sown in experiment were 1110. A fertilizer dose of 30-40-25 kg acre ${ }^{-1}$ of $\mathrm{N}$ : $\mathrm{P}$ : $\mathrm{K}$ was given uniformly at all three locations in the form of Urea, SSP and MOP for getting better yield. Average temperature data of all three locations was collected during the growing season and presented in (Table 2a, 2b \& 2c). Data was collected for seed emergence (\%), main stem length $(\mathrm{cm})$, number of branches plant $^{-1}$, number of leaves plant ${ }^{-1}$, number of flowers plant ${ }^{-1}$, number of pods plant ${ }^{-1}$, pod length $(\mathrm{cm})$, seeds pod $^{-1}$, fresh seed weight plant $^{-1}(\mathrm{~g})$, fresh seed weight (g/plant), fresh pod yield plant ${ }^{-1}(\mathrm{~g})$ and fresh pod yield ( $\mathrm{t} / \mathrm{ha})$.

\section{Statistical analysis}

Collected data was analysed statistically under Randomized Complete Block Design. All the tests were performed at probability level of 0.05 , with software MSTATC. Means were compared using Duncan's multiple range (DMR) test and further subjected to LSD test for comparison of their means [13].

\section{Results}

Seed emergence $(\%)$, main stem length (cm), number of branches plant ${ }^{-1}$

Significant difference among all the altitudes was observed for seed emergence, stem length and number of branches. Maximum seed emergence was recorded at Pallandri Gorah followed by Tolipir Bunbeck and Rawalakot city locations. Pea seeds sown in Pallandri Gorah showed 1.02 and 1.3-fold higher seed emergence percentage than Tolipir 
Bunbeck and Rawalakot city locations, respectively. Whereas, plant stem length was higher in Tolipir Bunbeck location that was 1.03 and 1.1-fold higher, as compared to Pallandri Gorah and Rawalakot city, respectively. Similarly, Tolipir Bunbeck location established its

Table 1. Salient characters of cv. 'Meteor'

\begin{tabular}{|c|c|c|}
\hline 1 & $\begin{array}{c}\text { Seedling } \\
\text { Height }(\mathrm{cm}) \\
\text { Seedling and cotyledon color }\end{array}$ & $\begin{array}{c}5-6.5 \\
\text { Green } \\
\end{array}$ \\
\hline 2 & $\begin{array}{c}\text { Adult plant } \\
\text { Growth type } \\
\text { Plant height }(\mathrm{cm}) \\
\text { Productive branches } \\
\text { Plant shape } \\
\text { Leaf color } \\
\text { Leaf type } \\
\text { Leaf length and width }(\mathrm{cm}) \\
\text { Stipula length and width }(\mathrm{cm}) \\
\text { Tendril size }(\mathrm{cm}) \\
\end{array}$ & $\begin{array}{c}\text { Determinate } \\
36-52 \\
2-5.5 \\
\text { Semi erect } \\
\text { Green } \\
\text { Compound } \\
4.62 \text { and } 2.56 \\
5.4 \text { and } 4.46 \\
11.86 \\
\end{array}$ \\
\hline 3 & $\begin{array}{c}\text { Flower } \\
\text { Days to } 50 \% \text { flowering } \\
\text { No. of petals and sepals }\end{array}$ & $\begin{array}{c}30-45 \\
5 \\
\end{array}$ \\
\hline 4 & $\begin{array}{c}\text { Fruit } \\
\text { Pod color } \\
\text { Pod length } \\
\text { Width }(\mathrm{cm}) \\
\text { Pod angle } \\
\text { Pod flavor } \\
\text { Seed per pod } \\
\text { Average green pod yield }(\mathrm{t} / \mathrm{ha}) \\
\text { Potential green pod yield }(\mathrm{Mt} / \mathrm{ha})\end{array}$ & $\begin{array}{c}\text { Green } \\
6-7 \\
1-1.5 \\
\text { Drooping } \\
\text { Sweet } \\
4-6 \\
6.4 \\
12.25\end{array}$ \\
\hline 5 & $\begin{array}{c}\text { Seed } \\
\text { Seed color } \\
\text { Seed shape } \\
\text { Seed surface } \\
100 \text { seed weight }(\mathrm{g})\end{array}$ & $\begin{array}{l}\text { Bright green } \\
\text { Round } \\
\text { Smooth } \\
45\end{array}$ \\
\hline
\end{tabular}

Source: [14]

Table 2a. Maximum and minimum temperature in Pallandri Gorah

\begin{tabular}{|c|c|c|c|c|}
\hline Temperature $\left({ }^{\mathbf{O}} \mathbf{C}\right)$ & May & June & July & August \\
\hline Maximum & 29.04 & 31.31 & 32.68 & 29.23 \\
\hline Minimum & 13.04 & 19.86 & 15.95 & 15.72 \\
\hline Average & 21.04 & 25.58 & 24 & 22.47 \\
\hline
\end{tabular}

Source: [15]

Table 2b. Maximum and minimum temperature in Rawalakot city

\begin{tabular}{|c|c|c|c|c|}
\hline Temperature $\left({ }^{\mathbf{}} \mathbf{C}\right)$ & May & June & July & August \\
\hline Maximum & 23.22 & 23.22 & 29.63 & 26.18 \\
\hline Minimum & 10.86 & 15.86 & 16.18 & 13.23 \\
\hline Average & 17.04 & 22.75 & 21.18 & 19.69 \\
\hline
\end{tabular}

Source: [15] 
Table 2c. Maximum and minimum temperature in Tolipir Bunbeck

\begin{tabular}{|c|c|c|c|c|}
\hline Temperature $\left.\mathbf{(}^{\mathbf{}} \mathbf{C}\right)$ & May & June & July & August \\
\hline Maximum & 19.18 & 24.36 & 22.77 & 20.86 \\
\hline Minimum & 8.81 & 13.81 & 13.22 & 12.55 \\
\hline Average & 13.99 & 19.08 & 17.99 & 16.71 \\
\hline
\end{tabular}

Source: [15]

Table 3. Effect of altitude variation on seed emergence, main stem length and number of branches plant ${ }^{-1}$ of summer pea cv. 'Meteor'.

\begin{tabular}{|c|c|c|c|}
\hline Treatments & $\begin{array}{c}\text { Seed } \\
\text { emergence (\%) }\end{array}$ & $\begin{array}{c}\text { Main stem length } \\
\text { (cm) }\end{array}$ & $\begin{array}{c}\text { No. of branches } \\
\text { plant }^{\mathbf{1}}\end{array}$ \\
\hline Pallandri & $92.38 \mathrm{~A}$ & $41.91 \mathrm{AB}$ & $4.34 \mathrm{~B}$ \\
\hline Rawalakot & $72.43 \mathrm{~B}$ & $38.40 \mathrm{~B}$ & $3.54 \mathrm{~B}$ \\
\hline Tolipir & $90.00 \mathrm{~A}$ & $43.53 \mathrm{~A}$ & $5.58 \mathrm{~A}$ \\
\hline Means & 84.93 & 41.28 & 4.48 \\
\hline LSD & 16.2 & 3.5 & 0.9 \\
\hline
\end{tabular}

Means with the same letter in a column do not significantly differ by the least significant difference (LSD) test at $\mathrm{p} \leq 0.05$ with RCBD

Number of leaves plant $^{-1}$, number of flowers plant ${ }^{-1}$ and number of pods plant $^{-1}$

All three altitudes exhibited significant variations regarding number of leaves, flowers and pods per pea plant. Pea plants grown at Tolipir Bunbeck location resulted in significantly higher number of leaves i.e. 1.08 and 1.20-folds higher than Pallandri Gorah and Rawalakot location; likewise, for number of flowers plant ${ }^{-1}$ it was 1.2 and 1.8-folds higher, respectively. Significantly less number of pods plant ${ }^{-1}$ was recorded in Rawalakot city location. Numbers of pods plant ${ }^{-1}$ were 2.1-folds higher at Tolipir Bunbeck location than Rawalakot city; whereas, different between Tolipir Bunbeck location and Pallandri Gorah was non-significant for number of pods plant ${ }^{-1}$ (Table 4).

Pod length $(\mathrm{cm})$, number of seeds $\operatorname{pod}^{-1}$ and fresh seed weight plant $^{-1}(\mathrm{~g})$

Pod length was 1.01 and 1.25-folds higher at Tolipir Bunbeck than other locations (Pallandri Gorah and Rawalakot city) which revealed non-significant results among the three treatments. Furthermore, seeds pod ${ }^{-1}$ also exhibited non-significant differences in all the altitudes. However, significant differences were observed in all three locations for fresh seed weight plant $^{-1}$. Significantly higher values for fresh seed yield plant ${ }^{-1}$ were observed at Tolipir Bunbeck and Pallandri Gorah locations showing about 1.34 and 1.7folds higher, as compared to Rawalakot city location (Table 5).

Fresh seed weight (t/ha), fresh pod yield plant $^{-1}$ and fresh pod yield (t/ha)

Fresh seed weight calculated in tons per hectare also revealed significant difference among all three locations. Tolipir Bunbeck location expressed its superiority by maintaining 2.13-folds higher fresh seed weight than Rawalakot location. Moreover, pea plants grown at Pallandri Gorah also exhibited 1.5-folds higher fresh seed weight than Rawalakot location. Similarly, fresh pod yield plant ${ }^{-1}$ and fresh pod yield hectare ${ }^{-1}$ also showed significant differences among all three locations. Highest fresh pod yield plant ${ }^{-1}$ (83.8) was observed at Tolipir Bunbeck location resulting in 1.32 and 2.1 -folds higher than other two locations i.e. Pallandri Gorah and Rawalakot city, respectively. Likewise, pod yield hectare ${ }^{-1}$ was significantly more than other two locations. Lowest pod yield hectare ${ }^{-1}$ (6 tons) was recorded at Rawalakot location; whereas maximum pod yield hectare ${ }^{-1}(13$ tons) was recorded at Tolipir Bunbeck location (Table 6). 
Table 4. Effect of altitude variation on number of leaves plant ${ }^{-1}$, number flowers plant ${ }^{-1}$ and number of pods plant ${ }^{-1}$ of summer pea cv. 'Meteor'

\begin{tabular}{|c|c|c|c|}
\hline Treatments & $\begin{array}{l}\text { No. of leaves } \\
\text { plant }^{-1}\end{array}$ & No. of flowers plant ${ }^{-1}$ & $\begin{array}{l}\text { No. of pods } \\
\text { plant }^{-1}\end{array}$ \\
\hline Pallandri & $80.42 \mathrm{AB}$ & $34.20 \mathrm{~A}$ & $20.90 \mathrm{~A}$ \\
\hline Rawalakot & $71.92 \mathrm{~B}$ & $22.00 \mathrm{~B}$ & $12.10 \mathrm{~B}$ \\
\hline Tolipir & $87.14 \mathrm{~A}$ & $40.20 \mathrm{~A}$ & $25.60 \mathrm{~A}$ \\
\hline Means & 79.82 & 32.13 & 19.53 \\
\hline LSD & 13.5 & 6.9 & 5.0 \\
\hline
\end{tabular}

Means with the same letter in a column do not significantly differ by the least significant difference (LSD) test at $\mathrm{p} \leq 0.05$ with RCBD

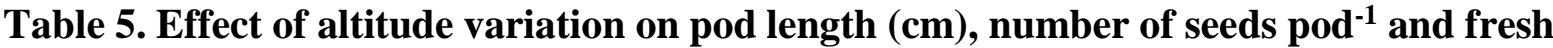
seed weight plant $^{-1}$ (g) of summer pea cv. 'Meteor'

\begin{tabular}{|c|c|c|c|}
\hline Treatments & Pod length $(\mathbf{c m})$ & Seeds pod $^{-1}$ & Fresh seed weight plant $^{-1}(\mathbf{g})$ \\
\hline Pallandri & $6.49 \mathrm{~A}$ & $5.18 \mathrm{~A}$ & $36.02 \mathrm{~B}$ \\
\hline Rawalakot & $5.24 \mathrm{~B}$ & $4.01 \mathrm{~A}$ & $28.51 \mathrm{C}$ \\
\hline Tolipir & $6.59 \mathrm{~A}$ & $5.13 \mathrm{~A}$ & $48.76 \mathrm{~A}$ \\
\hline Means & 6.10 & 4.77 & 37.76 \\
\hline LSD & 0.8 & 1.2 & 3.2 \\
\hline
\end{tabular}

Means with the same letter in a column do not significantly differ by the least significant difference (LSD) test at $\mathrm{p} \leq 0.05$ with RCBD

Table 6. Effect of altitude variation on fresh seed weight (t/ha), fresh pod yield plant ${ }^{-1}$ and fresh pod yield ( $t / h a)$ of summer pea cv. 'Meteor'

\begin{tabular}{|c|c|c|c|}
\hline Treatments & $\begin{array}{c}\text { Fresh seed weight } \\
(\mathrm{t} / \mathrm{ha})\end{array}$ & $\begin{array}{l}\text { Fresh pod yield } \\
\text { plant }^{-1}(\mathrm{~g})\end{array}$ & Fresh pod yield (t/ha) \\
\hline Pallandri & $5.92 \mathrm{~B}$ & $63.10 \mathrm{~B}$ & $10.38 \mathrm{~B}$ \\
\hline Rawalakot & $4.69 \mathrm{C}$ & $39.90 \mathrm{C}$ & $6.56 \mathrm{C}$ \\
\hline Tolipir & $8.02 \mathrm{~A}$ & $83.80 \mathrm{~A}$ & $13.78 \mathrm{~A}$ \\
\hline Means & 6.21 & 62.26 & 30.24 \\
\hline LSD & 0.52 & 13.1 & 2.16 \\
\hline
\end{tabular}

Means with the same letter in a column do not significantly differ by the least significant difference (LSD) test at $\mathrm{p} \leq 0.05$ with RCBD

\section{Discussion}

Seeds emergence started within 12 days and all the seeds were emerged till 15 days after sowing. Elzebroek and Wind [7] also observed seed emergence in peas between 10 to 14 days. Maximum emergence observed at Pallandri Gorah location may ascribe to relative higher temperature $\left(21^{\circ} \mathrm{C}\right.$ ) during emergence period (Table 2a); however, organic soils in Tolipir Bunbeck also showed better seed emergence percentage. However, reduced seed emergence percentage in Rawalakot location could refer to high clay contents in Rawalakot valley [16], as clay soil inhibits the efficiency of nutrient absorption [17]. Tolipir Bunbeck and Pallandri Gorah did not show significant difference for stem length; however, stem length at Tolipir Bunbeck location (43.53 $\mathrm{cm})$ was relatively higher due to favourable average temperature of 13$19^{\circ} \mathrm{C}$ during May to July (Table 2c). Bozoglu et al. [18] found average stem length of $50.59 \mathrm{~cm}$ in pea accessions grown at Samsun, Turkey; with the average temperature of $17^{\circ} \mathrm{C}$ in the months of May and $22^{\circ} \mathrm{C}$ in June and July. Whereas, less increase in stem length at Rawalakot city location could be due to 
high clay content in soil, as Okcu et al. [17] reported that clay contents in soil inhibited nutrient uptake resulting less vegetative growth of peas. Similarly, Ullah et al. [19] and Jan et al. [20] also recorded $50 \mathrm{~cm}$ stem lengths in pea cv. 'Meteor', cultivated in Upper Kaghan Valley of Pakistan during the spring season where average temperature in May June, July was $18^{\circ} \mathrm{C}, 22^{\circ} \mathrm{C}$ and $24^{\circ} \mathrm{C}$, respectively. Number of branches were more in pea plants grown at Tolipir Bunbeck location (5.5), which could be due to favourable temperature conditions in June $\left(19.0^{\circ} \mathrm{C}\right)$ and July $\left(17.9^{\circ} \mathrm{C}\right)$ required for growth (Table 2c) [15]. Furthermore higher organic matter content at Tolipir Bunbeck might also have induced more number of branches and similar observation was also reported by Walker et al. [21] who increase in organic matter with increase in elevation.

On the other hand, altitude difference did not show significant variation for number of leaves plant ${ }^{-1}$. Relatively higher numbers of leaves (87.14) were recorded at Tolipir Bunbeck location while 71.92 leaves were observed at Rawalakot location (Table 4). Reduced number of leaves could be attributed to low rainfall in the month of June and July 2014 i.e. $24 \%$ and $41 \%$ below normal, respectively. Moreover, increased flowering in Tolipir Bunbeck might be due to high intensity light with low temperature (Table 4). Flowering in many plant species can be regulated by environmental factors like low temperature and high-intensity light [22], as increased light intensity promote production of hormones like auxins and gibberellins [23]. Meanwhile, higher number pods plant ${ }^{-1}$ could be the result of higher seed yield or green pod yield [20, 24]. Pods plant ${ }^{-1}$ was more at Tolipir Bunbeck location (25.6) than Pallandri Gorah and Rawalakot locations. Higher number of pods Plant ${ }^{-1}$ recorded at Tolipir Bunbeck location could be due to favorable agro-climatic conditions required for pea growth. Our results closely match with the findings of Jan et al. [20] as they recorded 20.0 pods plant $^{-1}$ in summer pea cv. 'Meteor' grown at Kaghan valley KPK Pakistan (2450m asl.). Similar numbers of pods plant ${ }^{-1}$ (22.84 and 19.2) have also been reported in different pea cultivars grown at the elevation of $1701 \mathrm{~m}$ in Mastung region [25]. Less number of pod plant $^{-1}$ at Pallandri and Rawalakot location might be due high temperature at the time of flower initiation that could have reduced number of pods plant ${ }^{-1}[26,27]$.

Moreover, average pod length recorded for all three locations was $6.1 \mathrm{~cm}$ that is similar to the findings of Atif et al. [28] who observed the pod length of $6.27 \mathrm{~cm}$ in pea cv. 'Meteor' grown during spring at Rawalakot. However non-significant differences for number of seeds pod $^{-1}$ were observed among all three locations (Table 5). Similar results have also been reported by Atta et al. [29] as they found nonsignificant difference for seeds pod $^{-1}$ among six genotypes of peas, grown at Versailles in France, with the average temperature of $17.4^{\circ} \mathrm{C}$ in June and July. Similarly, Jan et al. [20] found 5.6 seeds per pod in pea lines grown during spring season with the average temperature of $22^{\circ} \mathrm{C}$ in Naran valley Pakistan; while in our experiment maximum of 5.2 seeds pod $^{-1}$ were observed at Pallandri Gorah location at an average temperature of $24^{\circ} \mathrm{C}$ during entire pods growth in June July and August (Table 2a). Non-significant results for pod length and seed pod $^{-1}$ could be related to a genetic trait of cv. 'Meteor', which remained similar at each location in our experiment. Slight decrease in pod length and number of seeds $\operatorname{pod}^{-1}$ at Rawalakot location can be related to stress conditions during July and August, as there was premature rotting of pods before harvest due to high rain fall and humidity in Rawalakot valley in August 2014 [15]. Meanwhile, Tolipir Bunbeck and Pallandri Gorah location resulted in higher fresh seed weight plant ${ }^{-1}$ that might be ascribed to higher number of pods than Rawalakot 
city location. Previously, similar resulted have been reported by Kazmi et al. [30] as they associated seed yield of pea plant with number of pods pea plant bearded. Reduction in seed fresh weight at Rawalakot city location in comparison with Tolipir and Pallandri locations could be due to high clay contents in the soil of Rawalakot that might have inhibited efficient nutrient uptake by plants and caused water stress resulting in reduced fresh seed yield.

Likewise seed weight $\mathrm{ha}^{-1}$ was significantly higher at Tolipir Bunbeck location that could be the result of higher seed plant ${ }^{-1}$ recorded at Tolipir Bunbeck (Table 6). Our results for fresh pod yield plant $^{-1}$ at Tolipir Banbeck location (83.80) closely match the findings of Achakzai and Bangulzai [25] in which they investigated role nitrogen doses on fresh pod yield of pea cvs. 'Climax', 'Arkel', 'Green Feast' and 'Olympia'. Likewise, maximum pod yield ha ${ }^{-1}$ was also recorded at Tolipir Bunbeck location that may express the conducive environment required for pea growth as noticed for other vegetative components like stem length, number of branches and leaves in pea cv. 'Meteor' grown at Tolipir location. The highest fresh seed and pod yield (t/ha) at Tolipir Bunbeck and Pallandri Gorah locations might be due to the sufficient organic matter and rainfall, Rawalakot city resulted in reduced yield due to increased rainfall or humidity which might have caused reduction in better crop growth rapid fungal attack. Our results for pod yield $\mathrm{ha}^{-1}$ closely match with findings of Ullah et al. [19] as they reported fresh pod yield of $10.55 \mathrm{t} / \mathrm{ha}$ in pea var. 'Misty' cultivated in upper Kaghan Valley at the elevation of $2450 \mathrm{~m}$ during spring.

\section{Conclusion and recommendations}

Pea cv. 'Meteor' grown at different altitudes showed significant variations in morphological and yield parameters. Evidently 'Tolipir Bunbeck' location exhibited higher values for plant height, number of branches, leaves and flowers per plant, pods per plant along with fresh seed weight and fresh pod yield. Maximum yield of fresh pods/ha was obtained at elevation of 2124 meters above sea level with $16-24^{\circ} \mathrm{C}$ average temperature under the normal rainfalls during spring. It can be concluded that pea being high value vegetable crop can be cultivated with improved quality characteristics at higher altitudes during summer season.

\section{Authors' contributions}

Conceived and designed the experiments: NA Abbasi \& IA Hafiz, Performed the experiments: S Qamar, Analyzed the data: M Shafique, S Qamar, AA Qureshi \& I Ali, Contributed materials/ analysis/ tools: NA Abbasi, M Shafique, S Qamar \& AA Qureshi, Wrote the paper: M Shafique \& S Qamar.

\section{Acknowledgements}

Corresponding author acknowledges Department of Horticulture PMAS-AAUR for facilitating the research.

\section{References}

1. Hussein MM, El-Gereadly NHM \& El-Desuki M (2006). Role of putrescine in resistance to salinity of pea plants (Pisum Sativum L.). J Appl Sci Res 2(9): 598-604.

2. Shahid M, Shah SFA, Ali H \& Ishtiaq S (2010) Resistance in pea germplasm/lines to powdery mildew under natural conditions. Mycopath 8(2): 77-80.

3. FAO http://www.fao.org/faostat/en/\#data/ QC

4. Khan TN, Ramzan A, Jillani G \& Mehmood T (2013). Morphological performance of Peas (Pisum Sativum) genotypes under rainfed conditions of pothowar region. J Agric Res 51(1): 51-60.

5. Hussain SA \& Badshah N (2002) Study on the adaptive behavior of exotic pea (Pisum sativum L.) varieties under local condition of Peshawar. Asian J Plant Sci 1(5): 567569. 
6. Shaukat SA, Ahmad Z, Choudhary YA \& Shaukat SK (2012). Effect of different sowing dates and row spacing on the growth, seed yield and quality of off-season pea (Pisum sativum L. $\mathrm{Cv}$. Climax) under temperate conditions of Rawalakot Azad Jammu and Kashmir. Agric Adv 1(5): 117-125.

7. Elzebroek T \& Wind K (2008). Guide to cultivated plants. CAB International; Oxfordshire, UK.

8. Manandhar N (2000). Vegetables and Pesticides - the Virtual Paradox, of Nepal Agriculture Research Council (NARC) Newsl 7(4).

9. Agricultural Statistics of Pakistan (2008). Govt. of Pakistan Ministry of Food, Agriculture and Livestock, Economic Wing, Islamabad.

10. Barry RG (1992). Mountain weather and climate. Psychology Press.

11. Yadav SP (2002). Performance of effective microorganisms (EM) on growth and yields of selected vegetables. Nat Farm Environ 1: 3538.

12. Azad Kashmir Statistical Year Book (1994). Planning and Development Department, Azad Govt. of the State of Jammu and Kashmir.

13. Steel RGD, Torrie JH \& Dickey D (1997). Principles and Procedures of Statistics: A Biometrical Approach 3rd edn. McGraw Hill Book Co. Inc. New York.

14. Nawab NN \& Rashid A (2014). 'Meteor Faisalabad', a high-yielding pea variety. Int J Veg Sci 20: 141-149.

15. Pakistan Meteorological Department (2014). http://www.pmd.gov.pk/cdpc /monsoon. 2014.pdf.

16. Malik MS, Abbasi MK \& Rahim N (2000). Laboratory study of physicalchemical characteristics and the nutrient status of soils collected from Rawalakot Azad Jammu and Kashmir. Pak J Biol Sci 3(12): 20822086.
17. Okcu G, Demir MK \& Atak M (2005). Effects of salt and drought stress on germination and seedling growth of pea (Pisum sativum L.). Turk J Agric Fores 29: 237-242.

18. Bozoglu H, Peksen E, Peksen A \& Gulumser A (2007). Determination of the yield performance and harvesting periods of fifteen pea cultivars sown in autumn and spring. Pak J Bot 39(6): 2017-2025.

19. Ullah I, Jadoon M, Rehman AU, Khan K \& Zeb T (2013). Screening of pea cultivars for yield and resistance towards powdery mildew in dry temperate zone, Kaghan Valley. Asian J Agric Sci 5(4): 71-73.

20. Jan H, Muhammad A, Sajid M, Rahman A, Iqbal N \& Nawaz A (2007). Screening of advanced pea lines for yield and resistance against Powdery Mildew in Kaghan valley (NWFP), Pakistan. Sarhad J Agric 23(2): 441.

21. Walker DA, Molenaar JG \& Billings WD (2000). Snow-vegetation interactions in tundra environments. In: Jones HG, Pomeroy J, Walker DA, Wharton R, editors. Snow Ecology. Cambridge University Press, Cambridge, UK. pp 264-322.

22. Botcha, S, Prattipati SD, Hemalatha AA \& Jyothi KP (2013). Studies on antioxidants and peroxidase isoenzymes in seedlings of twelve cultivars with four different durations of flowering time in pigeon pea (Cajanus cajan (L.) Millspaugh). Free Radicals and Antioxidants 3: 6772.

23. Abou EY (2011). Growth, biochemical constituents and yield of snap bean as influenced by low gamma irradiation doses under different sowing dates. Aust J Basic Appl Sci 5(11): 30-42

24. Tyagi MK \& Srivastava CP (2002). Genetic variability and correlations among yield and yield characters over 
two environments in pea. Ind J Agric Res 36: 53-56.

25. Achakzai AKK \& Bangulzai MI (2006). Effect of various levels of nitrogen fertilizer on the yield and yield attributes of pea (Pisum sativum L.) cultivars. Pak J Bot 38(2): 331340.

26. Konsens I, Ofir M \& Kigel J (1991). The effect of temperature on the production and abscission of flowers and pod in snap bean (Phaseolus vulgaris L.). Ann Bot 67: 391-399.

27. Gross Y \& Kigel J (1994). Differential sensitivity to high temperature of stages in the reproduction development of common beans (Phaseolus vulgaris L.). Field Crops Res 36: 201-212.
28. Atif MJ, Shaukat SA, Ali Shah MI, Choudry YA \& Shaukat SK (2014). Effect of different levels of phosphorus on growth and productivity of pea (Pisum sativum L.) cultivars grown as off-season under Rawalakot Azad Jammu and Kashmir conditions. $J$ Recent $A d v$ Agric 2(6): 252-257.

29. Atta S, Maltese S \& Cousin R (2004). Protein content and dry weight of seeds from various pea genotypes. Agronomie 24: 257-266.

30. Kazmi MR, Jeelani G \& Bhatti MH (2002) Yield potential of some promising pea cultivars against powdery mildew. Pak J Agric Res 17: 97-98. 